\title{
Teacher attractiveness of ingressants in Pedagogy course ${ }^{1}$
}

\author{
SILVA, Kíssila Ferreira Magro da (Brasil, Rio de Janeiro, Campos dos Goytacazes) ${ }^{1 *}$ \\ CORREAA, Carla Patrícia Quintanilha (Brasil, Rio de Janeiro, Campos dos Goytacazes) $)^{2 *+}$ \\ ${ }^{1}$ Prefeitura Municipal de Campos dos Goytacazes \\ ${ }^{2}$ Instituto Superior de Educação Professor Aldo Muylaert \\ ORCID ID: https://orcid.org/0000-0002-2766-8890 \\ ORCID ID: http://orcid.org/0000-0001-9934-8151**
}

\begin{abstract}
This article discusses the attractiveness of teachers among newcomers to the Pedagogy Course. The objective was to know the motivation for students to enter the first period of the course, since the teaching profession seems to be undervalued. The article describes and analyzes the current context of teaching, highlights the issue of teacher appreciation and career attractiveness. It also brings the results of field research conducted with the 65 students of the 1st period of the Pedagogy Course, from a state institution, in a city of Rio de Janeiro / Brazil, who answered a questionnaire in the 2 nd semester of 2018. Research indicates that the Pedagogy Course was not the first college option for most students, who chose it for a variety of reasons. The most cited were: enjoying working with children and the opportunity to complete their studies.
\end{abstract}

\section{Keywords}

Teaching attractiveness. Teacher appreciation. Teaching.

\section{Atratividade docente entre os ingressantes no curso de Pedagogia}

\begin{abstract}
Resumo
O presente artigo discute a atratividade docente entre os(as) ingressantes no curso de Pedagogia. O objetivo foi conhecer a motivação para o ingresso dos(as) alunos(as) no primeiro período do curso, uma vez que a profissão docente parece estar desvalorizada. $O$ artigo descreve e analisa o contexto atual da docência, destacando a questão da valorização docente e da atratividade da carreira. Traz ainda os resultados de pesquisa de campo realizada com 65 alunos(as) do primeiro período do curso de Pedagogia de uma instituição estadual em um município do estado do Rio de Janeiro/Brasil, que responderam a um questionário no segundo semestre de 2018. A pesquisa indica que o curso de Pedagogia não era a primeira opção de curso superior da maior parte dos(as) alunos(as), que o escolheram por diversos motivos. Os mais citados foram gostar de trabalhar com crianças e a oportunidade de concluir os estudos.
\end{abstract}

\section{Palavras-chave}

Atratividade docente. Valorização docente. Docência.

\footnotetext{
${ }_{1}^{1}$ Agradecemos ao professor Edno Gonçalves Siqueira, coordenador de pesquisa e extensão acadêmicas do curso de licenciatura em Pedagogia do Instituto Superior de Educação Professor Aldo Muylaert (Isepam), que gentilmente traduziu este artigo para a língua inglesa.
} 


\title{
Atractividad de la carrera docente entre los ingresantes
}

en el curso de Pedagogía

\begin{abstract}
Resumen
Este artículo discute el atractivo de los docentes entre los recién llegados al curso de Pedagogía. El objetivo era conocer la motivación para que los estudiantes ingresen al primer período del curso, ya que la profesión docente parece estar infravalorada. El artículo describe y analiza el contexto actual de la enseñanza, destaca el tema de la apreciación del maestro y el atractivo profesional. También trae los resultados de la investigación de campo realizada con los 65 estudiantes del primer período del curso de Pedagogía de una institución estatal en una ciudad de Río de Janeiro/Brasil, que respondieron un cuestionario en el segundo semestre de 2018. La investigación indica que el curso de Pedagogía no fue la primera opción universitaria para la mayoría de los estudiantes, que lo eligieron por una variedad de razones. Las más citados fueron: disfrutar trabajando con niños y la oportunidad de completar sus estudios.
\end{abstract}

Palabras clave

Atractivo docente. Apreciación del maestro. Enseñanza.

\section{INTRODUCTION}

Opting for a College degree, choosing a career is not always an easy task. There are many options available and several are the relevant factors at this time. In addition to aptitude or vocation, factors such as the social valorization of the profession, working conditions, remuneration, among others (CARDOSO et al., 2016) are also considered. In addition, it is noteworthy that certain professions are more valued by society than others. Regarding the teaching career, the significant decrease in its demand for high school graduates is worrying (OLIVEIRA, 2013), situation which results in the lack of teaching professionals in some subject matters. This issue becomes, therefore, subject for discussions, academic articles and it has been debated also by the media.

Given this situation, this research aims to investigate the attractiveness of the teacher career among the newcomers in the Degree in Pedagogy (Education College). The goal is to know the motivation for students to enter the 1 st period of that course, since the teaching profession seems to be undervalued and to have low social status (LOUZANO et al., 2010). To achieve the proposed objective, a field research was carried out by means of the questionnaire technique, applied to students of the 1st

Educação \& Formação, Fortaleza, v. 5, n. 13, p. 59-78, jan./abr. 2020

DOI: https://doi.org/10.25053/redufor.v5i13.1468

http://seer.uece.br/redufor 
period of the Pedagogy Degree Course of a state institution, located in a city of Rio de Janeiro State (RJ / Brazil). Sixty five undergraduates agreed to contribute to the study. The analysis of the information collected through the questionnaire allowed us to make some considerations on the issue of the teacher career attractiveness.

The present work was organized in three moments. Firstly, the current context of teaching with its multiple challenges will be analyzed. Then, we highlight the issue of teacher appreciation, remuneration, career and working conditions, initial and continuing education, and its attractiveness. Then, the data collected through field research with the students of the 1st period of the Pedagogy Degree Course in the 2nd semester of 2018 will be presented.

In this study, there is no pretension of exhausting the thematic approached because the teaching career debate is an extensive discussing subject, which still leaves much to be discussed. The expectation of this work is to provoke a reflection over the theme, so to contribute to build a greater appreciation of this profession, so relevant to society.

\section{21ST CENTURY TEACHING: MULTIPLE CHALLENGES}

To approach the teaching profession is to mention a complex field of action that has become the subject of discussion and reflection. In Brazil, the issue of teacher preparation arises after Brazil's Independence, when there was a growing concern about popular education. Since then, the teaching career has undergone several transformations over the last two centuries (SAVIANI, 2009).

We agreement with Hagemeyer (2004, p. 70) who affirms that "[...] it has never been so difficult to be a teacher as it is today". According to this author, "[...] the trajectory of the teaching profession is closely linked to the history of school education and the impasses and challenges it faces" and is also closely linked to the transformations that have occurred in society over the last years.

With the Industrialization, the world social scenario has changed and such changes have reflected in many sectors, including the school environment. According to Dubet (2011), the role of the school, for example, for a long time was to teach the citizen that he is a member of a nation. It was up to the teacher to transmit a whole set of cultural 
symbols, emphasizing the national culture. However, with the transformations that occurred worldwide, nowadays teachers have to teach the student not only the national culture, but also other cultures that make up contemporaneity.

Dubet (2011) discusses how teachers can pass on this diversity of cultural knowledge to their students if they often do not even have it. Another disturbing question for the teacher today concerns the complex competencies that they need to help students develop.

Today, citizen competences seem extremely complex because political life is divided between the levels of the municipality and the region, those of the nation and those of Europe. At the same time, democracy has led to a broad expansion of cultural and social rights. To make a political choice, the citizen must be much more informed. (DUBET, 2011, p. 298).

Thus, teaching work also becomes more complex because it needs to help students understand their responsibilities and rights. The role of training the student for life in society ends up being delegated to the teacher. According to Dubet (2011), before that, it was necessary to make children read. Now, with those mentioned changes, it is necessary that children be also prepared to keep up with technological advances. Watching television and surfing the WWW have become essential requirements for a well-informed citizen. According to the author, "[...] the school cannot ignore this fact and the media are increasingly present in teaching" (DUBET, 2011, p. 298).

There are many values and principles, contradictions that are present in the school environment and that end up becoming another challenge which the teacher needs to deal with. There is also the question of the objective of the work developed at school. Once the purpose of the school was to educate the citizen, to teach him to read, write and impart culture to him. Today the purpose of the school is to qualify students, to give them a diploma, because "[...] students and their parents come to school to seek qualifications in a diploma for the labor market" (DUBET, 2011, p. 301).

Therefore, it can be considered that the school has become an institution that seeks agreements and contracts. It is no longer about teaching itself and cultural training, but about producing goods and services. Schools have become a kind of market (DUBET, 2011). 
Nowadays, there is an increasing demand on the school, making it responsible for forming a critical citizen, aware of his rights and duties, prepared to keep up with the new technological demands and prepared, above all, with the best diplomas, with the best qualifications to compete for the best jobs opportunities.

However, according to Lantheaume (2012), although the circumstances of teaching work are changing and the demands are increasing, necessary resources are not always provided for the teaching to be properly developed. It can be said that " $[. .$. teachers difficulties are linked much more to the work environment than to personal inconveniences that they would lead to in the classroom" (LANTHEAUME, 2012, p. 372).

There is a lack of incentives to prepare teachers to respond to new career demands, so that, seeking to remedy the uneasiness caused by the multiple expectations of their work, many have been seeking new solutions to deal with the problems that arise in everyday life, "[...] looking to control situations, restoring low selfesteem, compensating for energy loss, disengagement and lack of recognition" (LANTHEAUME, 2012, p. 373).

However, some of the strategies used to deal with the profession daily life are somewhat defensive. According to Lantheaume (2012, p. 375), to deal with aggression, disappointment, uncertainty and adversity, many teachers choose to harden themselves, or as mentioned by a teacher interviewed by the author, "You need to arm yourself", so that it is possible to endure the unforeseen that arise in the profession and to continue the work even in the face of difficulties.

It is a matter of resignation, of being conformed with problems, since finding a solution seems impossible, what remains for the teacher is to continue working even in the face of difficulties, but there are also those teachers who, even in the face of difficulties, do not get accustomed to the problems, failures and the feeling of worthlessness. They choose to adapt their work to perform it to the best of their abilities. For them, it is necessary to "[...] adapt the rule, modify it, relativize it, reinterpret it, create other rules, negotiate situations and norms in a pragmatic perspective, this is one of the main ways for teachers to face the tests of the job" (LANTHEAUME, 2012, p. 377).

Thus, these teachers seek to improve their classes by proposing tools and activities that can help to overcome some problems. According to Lantheaume (2012, p. 
379), this requires "[...] the spirit and energy required to create these activities", which can result in a process of wearing and tearing over time.

Several researches have sought to analyze the subject of teaching today investigating teacher training courses, including the Degree in Pedagogy, which was the focus of this research (BARRETO, 2015; GATTI, 2010, 2014; GONÇALVES, 2017; MARIN; GIOVANNI, 2013; PIMENTA et al., 2017; SARTI, 2019). In general, these studies reveal that the profile of the students who seek the Pedagogy Course is mostly constituted by females (MARIN; GIOVANNI, 2013) who study and have at least two jobs, with base school disabilities coming from the public school (GATTI, 2014); often opting for distance learning courses (BARRETO, 2015) or even in-person courses, and also have a weak curriculum (GATTI, 2010; PLACCO; SOUZA; ALMEIDA, 2012; PIMENTA et al., 2017).

Given that context, the devaluation of the teaching profession has been established in the current society scenario, contributing to the young high school graduates do not want to choose the teaching career.

\section{TEACHER VALUATION AND ATTRACTIVITY}

According to Oliveira (2013), the appreciation of education professionals is a theme very present in the Brazilian educational debate. Therefore, when talking about career three important elements are highlighted, which interfere with the condition of this professional. They are: 1) remuneration, 2) career and working conditions and 3) initial and continuing education. Regarding the valuation of education professionals, the Law of Guidelines and Bases of National Education (LDBN) of 1996, in article 67, highlights that:

The education systems will promote the valorization of the professionals of the education, assuring them, including in the terms of the statutes and the career plans of the public teaching: I - entrance exclusively by public competition of tests and titles; II - continuing professional development, including periodic paid licensing for this purpose; IIIprofessional salary floor; IV - functional progression based on qualification or qualification, and performance evaluation; V - period reserved for studies, planning and evaluation, included in the workload; $\mathrm{VI}$ - adequate working conditions.

Educação \& Formação, Fortaleza, v. 5, n. 13, p. 59-78, jan./abr. 2020 
The enactment of this law was a great achievement for education professionals, and demonstrated that the theme of the appreciation of these professionals and their working condition deserve attention.

On July 16, 2008, Law №. 11,738 was enacted, which deals specifically with remuneration (MASSON, 2017). This law establishes the National Teaching "Floor" and represented an important achievement for teacher appreciation. However, although there are laws that guide and guarantee such attribution of value, they were not enough to make education professionals feel valued. According to Masson (2017, p. 856), this is because:

Although there are regulations for the organization of teachers' career plans, this is given in varied forms, with a diversity of criteria and formats that make it difficult to define the minimum requirements for teaching careers and to ensure that teachers are properly valued.

Career plans are appropriate to the characteristics of teachers and their state and local networks, so that there are significant differences between salaries and salary levels from one state to another. It is observed that there are no criteria to equalize the salaries and the minimum requirements to guarantee the proper valorization of the teachers.

Working conditions were also contemplated in the National Education Guidelines and Bases Law, No. 9394/96, but there is still much to reflect on. According to Bauer, Cassetari and Oliveira (2017), there are many problems that lead teachers to consider their profession as an undervalued one. In addition to low payments, there are other aspects of the teaching work conditions that deserve attention, such as the environment at work, violence and feelings of insecurity, high expectations of parents and governors, and the limited opportunity for personal growth.

Another aspect that should be considered concerns to the increasing demands for teaching activity today. The teacher's work is becoming increasingly complex and demands increasing responsibilities, both in relation to the pedagogical activities themselves, and due to issues that go beyond mediation with knowledge, such as violence and drugs. (TARTUCE et al., 2010, p. 449).

In addition to what has already been mentioned, Tartuce et al. (2010) point out that the lack of organization and materials in schools, the lack of interest in learning for some students are factors that contribute to teacher attrition and for some to believe that the teaching career is very laborious and is not worthy. 
According to Louzano et al. (2010), other countries attract people to the teaching career by offering good salaries and investing in quality training. In Brazil, in addition to low salaries being a reason for the questioning of teachers, it is observed that those who enter teacher training are often the least prepared ones.

The literature indicates that the profession has attracted the population with the lowest cultural and economic background. It is unlikely that, in the short term, in Brazil, the quality of teachers can be improved through the attractiveness of students with a better cultural and economic profile. The alternative is to take this fact into account when modeling training courses, trying to overcome the gaps in basic education. (BAUER; CASSETARI; OLIVEIRA, 2017, p. 947).

According to Louzano et al. (2010, p. 553), other countries in the world "[...] endeavor not only to offer quality training to beginning teachers, but also opportunities and incentives for continuous professional development throughout their career", which unfortunately does not occur in Brazil, causing high school graduates not to find many incentives to opt for teaching (LOUZANO et al., 2010).

Louzano et al. (2010, p. 554) continue to emphasize that in other countries the "[...] interaction of future teachers with the school is intense. Class preparation, hands-on classes, and strategies for teaching students with learning disabilities are an important part of the teacher education course". In Brazil, the interaction of undergraduates with the basic school is very small, and it is not enough to prepare them for the daily life of a teacher. In addition, Tartuce et al. (2010) still discuss the fact that the teaching career has become less selective, because many teachers exercise their profession without sufficient preparation, which contributes to the belief that anyone can be a teacher, even without specific training.

There are also some factors considered attractive in relation to teacher education. Among them, Louzano et al. (2010, p. 548) highlight flexibility, vacations, low unemployment rates, and altruism as attractive factors. According to the authors, among the advantages of being a teacher there is flexibility, as most teachers have the option to adapt their work to their personal and financial needs. Teachers have the option of choosing to work full or part time and to work in various jobs. In addition, the teacher's vacations are generally longer than other professionals, as they have the same school vacations time. Another factor to be taken into consideration is the possibility of public 
tender in the area. According to research by Corrêa et al. (2019, p. 133), this may be the factor that makes teaching attractive to some students, as they seek "[...] the guarantees of public service".

According to Louzano et al. (2010), low unemployment rates also constitute an attractive factor for the teaching profession. In addition to altruism, because many choose the teaching career believing that somehow it can contribute to the development of society. However, according to Cardoso et al. (2016, p. 33), although teaching is "[...] a profession with deep meaning and human commitment", it is nonetheless a profession. Therefore, when choosing a career, many opt for those that are shown to be better paid and valued. Unfortunately, the unattractive factors in teaching career outweigh the attractive ones, thus leading to a significant decrease in demand for these courses. Given the above, a field research was conducted, seeking to probe these issues.

\section{ANALYZING FIELD SEARCH DATA}

The research was carried out in the 1st period classes of the Pedagogy Degree Course in a State Institution, in a city of Rio de Janeiro State (RJ / Brazil). In the second semester of 2018, the Course had 3 classes from the 1st period, totaling 150 students enrolled. Of these, 65 agreed to make their time available to complete a questionnaire. According to reports of some teachers, not all 150 enrolled attended the course at the time of the research.

The questionnaire consisted of 12 questions, 3 of them multiple choice, 3 closed and 6 open. The instrument was designed to obtain information that would allow a characterization of this student who chose the Pedagogy Course, including age group, if they worked, if this Course was their first option of higher education and why choice. The analysis of the information collected through the questionnaire allowed us to make some considerations.

It was found that $28 \%$ of the students who answered the questionnaire are under 20 years old, $55 \%$ are between 20 and 30 years old, $9 \%$ are between 31 and 40 years old and $8 \%$ of the students in the age group above 40 years. Considering that the expected age for completing high school is 17 years, it can be concluded that the 
Pedagogy course seems not to have been the option chosen by students who have recently completed high school, corroborating the findings of Louzano et al. (2010).

It was also found that $34 \%$ of respondents are reconciling the work with the Pedagogy course, while $66 \%$ are currently without work, which leads them to think that for them, the course in question It can be an opportunity to enter the job market. These data differ from those presented by Gatti (2014), who reveals that most undergraduates perform some type of occupation while studying, reducing their time of dedication to the course. In the case of most of the undergraduates of this research, there seems to be a greater possibility of dedication to the activities of the Pedagogy Course.

Regarding the undergraduates who are working, it was found that the 22 interviewed students work in several different areas. There are those who work as a secretary, receptionist, confectioner, seamstress, nanny, housekeeper, office clerk, clerk, accounting clerk, trader, in leafleting, pharmacy and also in a school environment, as a class assistant and teacher. Two (2) undergraduates mentioned working at a State University in the municipality, but did not mention in what function.

The answers to this question reflect the possibility that the Pedagogy Course is an opportunity to acquire improvement for those who already work in the school environment and as an opportunity to work in a greater diversity of areas for those who have the most varied professions.

Asked if the Pedagogy course was their first college option, 45 of the respondents, ie $69 \%$ answered no. Only 20 students, $31 \%$, consider this course as their first college option. These data confirm Oliveira's (2013) statement according to which, for many persons, teaching is a second option.

This became even more evident when these students who stated that the Pedagogy Course was not their first option were asked what would be the first option. It was found that there would not be many who would choose the teaching career. The first choice of two (2) respondents would be a degree in Geography, a degree in History, a degree in Biology, a degree in Chemistry, three a degree in Mathematics and three would Physical education, thus adding 11 students who would choose the teaching career, that is, only $17 \%$ of the total respondents.

The other 34 students out of the 45 students who would not opt for the Pedagogy Course, when answering about their first option of higher education, mentioned several 
areas such as: Administration, Social Work, Psychology, Law, Architecture, Aesthetics, Medicine, Veterinary, Nursing, Graphic Design, Human Resources, Nutrition, Advertising, Physiotherapy and Engineering. Most notably the Psychology Course, which was the first option of 8 students. Two (2) of the respondents mentioned that they had not only one first option, but two. One mentioned that he / she would like to have studied Medicine or Law, another would choose Law or Psychology, so that, in these cases, the Degree in Pedagogy was not even a second option.

According to Tartuce et al. (2010), many think they do not have the characteristics necessary for teaching, and do not consider it a valued profession. Therefore, according to Masson (2017), the demand for baccalaureate is three times higher than that of the Pedagogy Course and the undergraduate degrees, because for many, these professions are more valued and well paid than the teaching profession. To choose teaching is to be subject to a possible state of unrest (LANTHEAUME, 2012).

When asked if the Pedagogy course was their first higher education course, $86 \%$ of the students answered yes. Only 14\% answered that they had already attended another college. Two undergraduate students attended Mathematics, one Chemistry, one Biology, one Psychology, one Gastronomy, one Administration, one Accounting Science and one a) Production Engineering. But as already mentioned, most respondents are in the first college course.

According to Tartuce et al. (2010), many think they do not have the characteristics necessary for teaching, and do not consider it a valued profession. Therefore, according to Masson (2017), the demand for a bachelor degree is three times higher than that of the Pedagogy Course and the undergraduate degrees, because for many, these professions are more valued and well paid than the teaching profession. To choose teaching is to be subject to a possible state of unrest (LANTHEAUME, 2012).

Asked how they learned about the Institution's Pedagogy Course, it was found that 25 learned through friends, 16 through social networks, 6 from relatives, 4 through television or other media, 12 through other media and 2 heard about the course by two different means, as Table 1 illustrates. 
Table 1 - How you knew of the course

\begin{tabular}{l|c}
\hline \multicolumn{1}{c|}{ They learned about the course... } & № of participants \\
\hline Through friends & 25 \\
\hline By social networks & 16 \\
\hline Through relatives & 6 \\
\hline By television or other media & 4 \\
\hline Other & 12 \\
\hline *Marked two options & 2 \\
\hline \multicolumn{2}{c}{ Fonte: Author elaboration (2019). }
\end{tabular}

Of the 12 who ticked the other option, Table 2 presents the other means by which participants learned about the course.

Table 2 - Other means

\begin{tabular}{l|c}
\multicolumn{1}{c|}{ Outros meios } & № de participantes \\
\hline Enem or Sisu & 6 \\
\hline Poster in front of the Institution & 4 \\
\hline Teacher & 1 \\
\hline Not specified & 1 \\
\hline \multicolumn{2}{c}{ Fonte: Author elaboration (2019). }
\end{tabular}

Fonte: Author elaboration (2019).

Of those who pointed out two options, 1 stated that they heard about the course by friends and social networks and 1 by friends and the institution itself, as it was already a student there.

When asked why to choose the Pedagogy Course, it was found that there are many reasons. For 4 survey participants, working as a teacher was a dream. "It's a childhood dream. I always wanted to study Pedagogy to work with children in early childhood education. In my childhood my game was a little school', says one of the students.

Four respondents stated that they identify with the area and believe that being a pedagogue is their vocation. These may be identified with Tartuce et al. (2010) who claim that some people believe that there is a certain pleasure in being a teacher. According to the authors, for such people it seems rewarding to contribute to the learning of others.

Another factor mentioned was the family influence, which is evidenced in the answer given by these students, "I have people in the family who are a pedagogue and gave me the strength to do too", "I chose the course because of my mother's influence". Other 4 respondents mentioned that this was the reason that led them to choose the 
Pedagogy Course: to hear reports of family members who are teachers, besides the encouragement of these family members.

Another factor mentioned by many students who have chosen the Pedagogy Course is the opportunity to continue their studies: 11 answered that they took the Normal Higher Course and saw in this course a way to deepen their knowledge and continue their training.

There are also those who have chosen the course based on the job market. As presented previously, according to Louzano et al. (2010), one of the attractive factors of the teaching career is the low unemployment rate, as teachers rarely stay unemployed for a long time. For 6 students participating in the survey this was the deciding factor in making their choice. For them, it is easy to get a job in the area. This was evident in the words of one of the students explaining why they chose the course: "I chose to be a profession that provides employment".

There are still 11 students who would like to have taken another course. They mentioned that they did the Enem and with the grade they obtained it was not possible to enroll in the course they would like, so the Degree in Pedagogy was the available option. "That's what I could do with my Enem score", reported one of the respondents. "I decided to embrace the opportunity that came to me because I really wanted to study". According to Tartuce et al. (2010), the motivation of some people who enter the teaching profession is in the field of altruistic values and personal fulfillment. Many choose a teaching career because they enjoy teaching and working with children. This was confirmed in this research by verifying that 15 students chose this course because they enjoy working with children and education, 7 said that taking Pedagogy provides them with personal and / or professional achievement and 3 chose the course because they believe that They will be able to understand the learning process of the children and this knowledge will be useful to them on a daily basis.

According to the National Curriculum Guidelines for the Undergraduate Course in Pedagogy, undergraduate degree (Resolution CNE/CP No. 1/2006), the pedagogue is a professional with the possibility of acting in various environments ${ }^{2}$, the Students

2 "The Curriculum Guidelines for the Pedagogy course apply to initial training for teaching in early childhood education and in the early years of elementary school, in high school, in the standard mode, and in vocational education courses in the area of services. and school support, as well as in other areas where pedagogical knowledge is provided" (BRASIL, 2006, art. $2^{\circ}$ ).

Educação \& Formação, Fortaleza, v. 5, n. 13, p. 59-78, jan./abr. 2020

DOI: https://doi.org/10.25053/redufor.v5i13.1468

http://seer.uece.br/redufor 
were asked about the area in which they intend to work. Many have only found that the Pedagogy Course allows them to work in various environments after joining the course. This may be the reason why 21 of the respondents marked 3 or more options regarding the environment in which they intend to act. This leads to reflect that these undergraduates expect the course to open new possibilities for them to work in various areas. Table 3 presents the frequency of the professional choice of the participants. Of the 3 undergraduates who ticked the "other" option, one wants to work as a university teacher, one at a school office and one wants to be an educator in the Army or another Armed Force.

Tabela 3 - Professional choice frequency

\begin{tabular}{l|c}
\hline \multicolumn{1}{c|}{ Option } & Frequency \\
\hline Teacher from 0 to 5 years old & 31 \\
\hline Teacher of children 1st through 5th grade of elementary school & 24 \\
\hline Pedagogical coordinator of a school & 28 \\
\hline Principal of a school & 17 \\
\hline Pedagogue at a hospital & 8 \\
\hline Pedagogue in homeless shelters & 9 \\
\hline Tutor in a company & 3 \\
\hline Other & 3 \\
\hline
\end{tabular}

Fonte: Author elaboration (2019).

Looking at Table 3, it is possible to notice that most of the undergraduates intend to work in a school environment and, in this sense, most would choose to work as a teacher of children from 0 to 5 years old. According to Corrêa et al. (2019, p. 137), the reason for such preference may be the "[...] current common sense idea, which points out the work of the preschool teacher as the simplest to perform due to the age of the children". This idea disregards the fact that work in early childhood education can be much more complex because it requires teachers to develop daily work that addresses the various aspects of child development, not only the cognitive, but also the physical, emotional, among others.

Another aspect to highlight about Table 3 is the significant number of undergraduates who wish to work in management and pedagogical coordination activities in schools. This is an important point for reflection on the Pedagogy Course, as research indicates weaknesses in the education of the pedagogue who will work in these areas (PIMENTA et al., 2017; PLACCO; SOUZA; ALMEIDA, 2012). Similarly, the number of 
undergraduates who intend to work outside the school environment is also significant. Regarding this issue, Pimenta et al. (2017) warn, from the data of their study, that the curriculum matrix of the Pedagogy Course is still fragile in view of the necessary preparation of the pedagogue to work in non-school spaces. Thus, the Pedagogy Courses need to urgently problematize this issue, which involves not only the discussion of appropriate theoretical material, but also the entrance of the undergraduates in nonschool spaces to develop the internship.

The undergraduates were also asked about the necessary requirements for the profession of the pedagogue to be valued. According to the respondents of this research, there are several essential factors for the appreciation of the pedagogue. According to 9 of the respondents, one way to do this is to offer a training that best prepares them for the exercise of the teaching function, a training that includes theory and practice. In addition, programs are needed for the continuing education of these professionals, "[...] public policies that prioritize education and continuing education for teachers" are the requirements cited by one of the students.

According to Corrêa et al. (2019, p. 137), "[...] public policies aimed at teacher valorization are necessary, aiming to recover the attractiveness for the career". It is necessary that public policies are modified to recognize the importance and complexity of teaching work, as it involves much more than teaching reading and writing, also involves understanding each step of basic education to develop a pedagogical work that can contribute with the multiple aspects involved in child development.

Another requirement mentioned by students is the respect and acknowledgment of the importance of the Pedagogy professional by society. Of the participants, 22 mentioned this as a factor of great importance. This is evident in the speech of these students. "Teacher appreciation, that is, acknowledgment of the importance of educators and teachers in general in society". Another mentions "Being respected, people put this profession first and not last", and one respondent quotes "May people understand the value of the educator and teach children and youth to value and respect this essential professional for all'.

Still other requirements are highlighted by the survey participants: 15 mention better salaries, adequate working conditions and support for schools. According to data presented by a study by Hirata, Oliveira and Mereb (2019, p. 199), "[...] teachers receive, 
on average, less than other professionals with higher education in Brazil". This causes many to give up their teaching career and feel undervalued because they feel that the remuneration they receive does not match the work they do. There are still 6 undergraduates who said that the love of the profession and the dedication to what they do is enough to feel a valued professional, 7 mention the importance of having public policies that emphasize the importance of education, and acknowledgment by the rulers to the importance of the pedagogue and 6 did not answer what is necessary for this valorization to occur.

Regarding the expectation of the students with the Pedagogy course, 7 answered that their expectation is to get a job in the education area, showing, once again, that the choice for the course may have been made based on the labor market, because many believe it is easy to get a job. Only 1 student mentioned that their expectation with the course is also to enter the job market, but unlike the others 7 , this student does not want to work in the area of education, choosing the business or hospital environment.

Most interviewed students, 19 ones, mentioned that their expectation with the course is to expand and improve their knowledge in the area of education and 14 mention that their expectation is one day to be able to contribute their work to the training. and learning from others. This points to the placement of Tartuce et al. (2010) that the choice for the teaching profession is motivated by altruistic values, involves the desire to teach and the possibility of contributing in some way.

There are other expectations related to the Pedagogy course: 9 respondents mentioned that they expect to complete higher education, 7 mentioned that they are enjoying the course very much, so expectations are the best possible, 3 expect to be recognized and have prestige after Pedagogy training and 5 do not have any expectations with the course or do not know how to answer, have not thought about it.

\section{FINAL CONSIDERATIONS}

In this article, we sought to contribute to the debate on the attractiveness of the Degree in Pedagogy. The objective was to know the reasons for the students to get into the first period of the course. The results of the field research indicated that most of those who entered the course are not more than 30 years old, mostly unemployed, waiting with 
the course to have an opportunity to enter the job market or, in the case of those who are employees, acquire more knowledge and improvement to work in other areas.

The data also indicate that more than half of the participants did not have the Pedagogy Course as their first higher education option, but still did not have the opportunity to enter the other intended course. When asked as to why they chose the course, it was observed that there were several reasons that led them to study Pedagogy, but the most cited were enjoying working with children and the opportunity to complete their studies.

Through data analysis, it was possible to point out that most undergraduates are enjoying the course, which is an opportunity for them to improve and contribute to the learning of others. Even those who would choose another college course were excited about the Pedagogy Course, but they are aware that the daily life of a pedagogue may not be easy and that much can be done to make this professional more valued.

These data arouse reflection over the formative challenges faced by the Pedagogy Course nowadays, as it needs to contemplate students who did not want to join the teaching career, but faced with the lack of desired options, agreed to engage into it. The data reveal an apparent bend for the course activities and the opportunities for professional insertion brought by the new area embraced.

However, it is important to emphasize that the responsibility of the educator's training is significant, considering that the studies mentioned here show weaknesses in the formative proposals, especially in the performance in educational management and in non-school spaces. Given these aspects, there is urgency in the collective reflection on these and other challenges faced by the Pedagogy Course in contemporary times.

Finally, this study was not intended to exhaust the theme addressed, as the teaching career is an extensive subject, which still leaves much to be discussed. The intention was to provoke a reflection on the theme addressed, since, although the undergraduate degree was not the first option of its newcomers, the data of the present study indicate the involvement of the undergraduates with the Pedagogy, even aware of the devaluation of teachers faced in the country. 


\section{REFERENCES}

BARRETO, E. S. S. Políticas de formação docente para a educação básica no Brasil: embates contemporâneos. Revista Brasileira de Educação, Rio de Janeiro, v. 20, n. 62, p. $679-701,2015$.

BAUER, A.; CASSETARI, N.; OLIVEIRA, R. P. Políticas docentes e qualidade da educação: uma revisão de literatura e indicações de política. Ensaio: Avaliação e Políticas Públicas em Educação, Rio de Janeiro, v. 25, n. 97, p. 943-970, 2017.

BRASIL. Lei no 9.394, de 20 de dezembro de 1996. Estabelece as Diretrizes e Bases da Educação Nacional. Diário Oficial [da] República Federativa do Brasil, Poder Executivo, Brasília, DF, 21 dez. 1996.

BRASIL. Lei no 11.738, de 16 de julho de 2008. Regulamenta a alínea "e" do inciso III do caput do art. 60 do Ato das Disposições Constitucionais Transitórias, para instituir o piso salarial profissional nacional para os profissionais do magistério público da educação básica. Diário Oficial [da] República Federativa do Brasil, Poder Executivo, Brasília, DF, 17 jul. 2008.

BRASIL. Resolução CNE/CP no 5, de 13 de dezembro de 2005. Diretrizes Curriculares Nacionais para o Curso de Pedagogia. Diário Oficial [da] República Federativa do Brasil, Poder Executivo, Brasília, 16 maio 2006.

CARDOSO, M. C.; FIGUEIREDO, S. O.; SOARES, S. E. C. Atratividade da carreira docente na educação básica: Fios de reflexões sobre o prazer e o sofrimento da professoralidade. Revista de Iniciação à Docência, Vitória da Conquista, v. 1, n. 1, p. 2536, 2016.

CORRÊA, C. P. Q. et al. A atratividade da docência na educação infantil em ingressantes do curso de Pedagogia. Educação: Teoria e Prática, Rio Claro, v. 29, n. 60, p. 121-139, 2019.

DUBET, F. Mutações cruzadas: a cidadania e a escola. Revista Brasileira de Educação, Rio de Janeiro, v. 16, n. 47, p. 289-322, 2011.

GATTI, B. A. Formação de professores no Brasil: características e problemas. Educação e Sociedade, Campinas, v. 31, n. 113, p. 1355-1379, 2010.

GATTI, B. A. Formação inicial de professores para a educação básica: pesquisas e políticas educacionais. Estudos em Avaliação Educacional, São Paulo, v. 25, n. 57, p. 24-54, 2014.

GONÇALVES, S. R. V. O curso de Pedagogia no Brasil: da formação específica para a formação generalista. Revista Espaço do Currículo, João Pessoa, v. 10, n.2, p. 244-258, 2017. 
HAGEMEYER, R. C. C. Dilemas e desafios da função docente na sociedade atual: os sentidos da mudança. Educar, Curitiba, n. 24, p. 67-85, 2004.

HIRATA, G.; OLIVEIRA, J. B. A.; MEREB, T. M. Professores: quem são, onde trabalham, quanto ganham. Ensaio: Avaliação e Políticas Públicas em Educação, Rio de Janeiro, v. 27 , n. 102 , p. $179-203,2019$

LANTHEAUME, F. Professores e dificuldades do ofício: preservação e reconstrução da dignidade profissional. Cadernos de Pesquisa, São Paulo, v. 42, n. 146, p. 368-387, 2012.

LOUZANO, P. et al. Quem quer ser professor? Atratividade, seleção e formação docente no Brasil. Estudos em Avaliação Educacional, São Paulo, v. 21, n. 47, p. 543-568, 2010.

MARIN, A. J.; GIOVANNI, L. Formação de professores para o início da escolarização: fragilidades. Intermeio, Campo Grande, v. 19, n. 38, p. 52-68, 2013.

MASSON, G. Requisitos essenciais para a atratividade e a permanência na carreira docente. Educação \& Sociedade, Campinas, v. 38, n. 140, p. 849-864, 2017.

OLIVEIRA, D. A. As políticas de formação e a crise da profissionalização docente: por onde passa a valorização? Revista Educação em Questão, Natal, v. 46, n. 32, p. 51-74, 2013.

PIMENTA, S. G. et al. Os cursos de licenciatura em Pedagogia: fragilidades na formação inicial do professor polivalente. Educação e Pesquisa, São Paulo, v. 43, n. 1, p. 15-30, 2017.

PLACCO, V. M. N. S.; SOUZA, V. L. T.; ALMEIDA, L. R. O coordenador pedagógico: aportes à proposição de políticas públicas. Cadernos de Pesquisa, São Paulo, v. 42, n. 147, p. 754-771, 2012.

SARTI, F. M. O curso de Pedagogia e a universitarização do magistério no Brasil: das disputas pela formação docente à sua desprofissionalização. Educação e Pesquisa, São Paulo, v. 45, p. 1-18, 2019.

SAVIANI, D. Formação de professores: aspectos históricos e teóricos do problema no contexto brasileiro. Revista Brasileira de Educação, Rio de Janeiro, v. 14, n. 40, 2009.

TARTUCE, G. L. B. P. et al. Alunos do ensino médio e atratividade da carreira docente no Brasil. Cadernos de Pesquisa, São Paulo, v. 40, n. 140, p. 445-477, 2010.

\section{Kíssila Ferreira Magro da Silva (Brasil, Rio de Janeiro, Campos dos Goytacazes)}

Prefeitura Municipal de Campos dos Goytacazes

Degree in Pedagogy from the Higher Education Institute Professor Aldo Muylaert (Isepam). Kindergarten teacher at Campos dos Goytacazes municipal school, Rio de Janeiro.

Lattes: http://lattes.cnpq.br/5227244502557284.

E-mail: kissilafmagro.km@gmail.com. 


\section{Carla Patrícia Quintanilha Corrêa (Brasil, Rio de Janeiro, Campos dos Goytacazes)} Instituto Superior de Educação Professor Aldo Muylaert (Isepam)

$\mathrm{PhD}$ in Education from the Federal University of Juiz de Fora (UFJF) with postdoctoral degree in Education from UFJF. Lecturer in Pedagogy at the Higher Institute of Education Professor Aldo Muylart (Isepam).

Lattes: http://lattes.cnpq.br/4655143704136513.

E-mail: carlapqcorrea@hotmail.com.

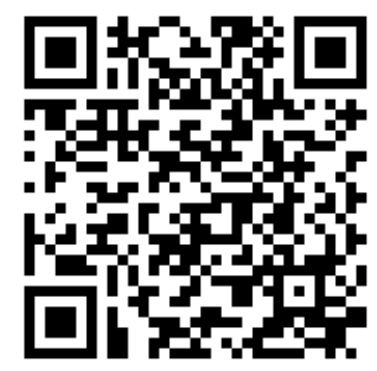

Received on August 6, 2019.

Accepted on November 4, 2019. 